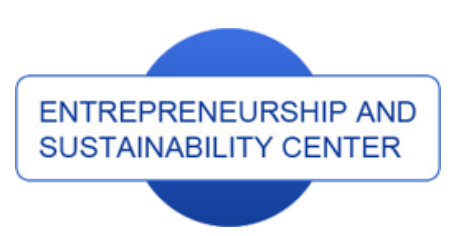

Publisher

http://jssidoi.org/esc/home enterprise

europe

network

Business Support on Your Doorstep
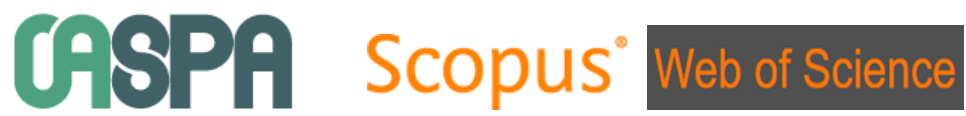

1) Clarivate

Analytics

\title{
PERCEPTION OF PRIVATE TELECOM EMPLOYEES TOWARDS UNFAIR HRM PRACTICES: AN EMPIRICAL INVESTIGATION
}

\author{
Nasser S. Al-Kahtani \\ Department of Human Resource Management, \\ College of Business Administration, Prince Sattam bin Abdulaziz University, Kingdom of Saudi Arabia \\ E-mail: $\underline{\text { ns.alkahtani@psau.edu.sa }}$
}

Received 10 March 2018; accepted 26 May 2018; published 30 June 2018

\begin{abstract}
The aimed of this research paper is to explore the unfair human resource management (HRM) practices in the private telecom company located in the Kingdom of Saudi Arabia. The total 120 employees were selected randomly from two private telecom companies to gather the information about the unfair HRM practices for this research. A questionnaire that consists of biographical information blank and unfair HRM practices was administered to the employees to identify the unfair HRM practices. The questionnaire was validated using appropriate techniques and the level of unfair HRM practices among the sample was assessed. The results of the study have provided some interesting findings relevant to the current industries. The investigator has incorporated certain suggestion to implement fair HRM practices so as to create vibrancy and passion among the employees to perform effectively.
\end{abstract}

Keywords: Telecom sector; Unfair HRM practices; construction and validation; Saudi Arabia

Reference to this paper should be made as follows: Al-Kahtani, N.S. 2018. Perception of private telecom employees towards unfair HRM practices: an empirical investigation, Entrepreneurship and Sustainability Issues 5(4): 957- 966. http://doi.org/10.9770/jesi.2018.5.4(18)

JEL Classifications: L26, O10, C20

\section{Introduction}

The topic of HRM practices attracted the attention of employer and employee in several ways over the decades and it is a universal truth that for any organization human resource is considered as one of the most important pillars and medium to accomplish the competitive advantage. Danish and Usman (2010) opined that success and growth of the organization depend on the employee, who considered employee as a valuable asset in the organization. As we know that human behavior is very complex and managing such behavior is one of the biggest challenges of the manager as compared to others like technology or finance to make the organization more viable, thereby, organization needs structure and such structure should be backed by human resource practices. This 
ISSN 2345-0282 (online) http://jssidoi.org/jesi/

2018 Volume 5 Number 4 (June)

http://doi.org/10.9770/jesi.2018.5.4(18)

particular research conducted on employees working in private telecom sectors in the Saudi Arabia to explore the understanding of fair or unfair HRM practices. The findings of the research would be added some new value or knowledge in the area of studies such as organizational behavior, organizational development and human resource management. The organizational success totally depends on equity treatment of the employees and development of the human resource. These treatments would help the employees to develop their organizations into ambidextrous ones (Sulphey and AlKahtani, 2017a) and take on the challenges faced by them in current world. Thereby, it can be considered to be the management responsibility to overcome or lessen the unfair HRM practices which are prevailing in any sectors and generate a conducive work environment in the form of fairness in the telecom sectors. These aspects are prerequisites to make the respective organizations have the badly required quality of sustainability (Sulphey, AlKahtani, 2017b; Jurigová et al., 2016). The indispensable role played by HR in creating sustainability in organizations has been highlighted by many studies (Korauš, Kaščáková, Parová and Veselovská, 2017; Prause, 2015). This is all the more important in countries like Saudi Arabia which is striving to make their workforce efficient, effective and productive.

\section{Review of literature}

On the globe numerous study has been initiated by the researchers on HRM practices with different variables, finally, they observed or suggested that fair HRM practices directly or indirectly increases the performance of the employees, enhancement of job satisfaction \& commitment, better career prospects, intention to stay in the organization, lower level of absenteeism, low turnover, minimizing the job stress, feeling comfortable to dealt with senior or junior or peer (Hassan 2016; Al Kahtani et al, 2016; Allam, 2017; Al Kahtani \& Allam, 2016; Ali \& Allam, 2016; Singh \& Kassa, 2016; Allam \& Harish, 2010; Tan \& Nasurdin, 2011; Al Kahtani \& Nawab, 2013: Boxall et al, 2011; Paauwe and Boselie, 2005; Allam, 2007; Lai, Saridakis, Johnstone, 2017; Mura et al. 2018; Katou and Budhwar, 2010).

Katou and Budhwar (2010) jointly conducted a study among 178 Greek organizations to check the impact of HRM on organizational performance. They found five HRM practices such as training and development, job design, employee participation, compensation \& incentives and recruitment. They observed positive relationships with HRM practices variable and organizational performance. Tan and Nasurdin (2011) conducted a study among employees working in Malaysia and revealed that HRM practices particularly training were found to be positively related to the dimensions of organizational innovation such as process innovation, product innovation and administrative innovation. Further, they opined that performance appraisal also has a significant impact on administrative innovation and both training\& performance appraisal led to associated effectively with knowledge management.

Lai \& Saridakis (2013) concluded that HR practices such as training \& development and recruitment \& selection are designed to improve the overall capabilities of the workforce, however, HR interventions like reward based on performance, incentive payment and appraisal are planned to inspire the employee to stay in the organization and put extra efforts at work to achieve the goals. It is noted that HR practices i.e. adequate training has no association with retention but still considered as one of the most vital components of employee retention and satisfaction (Terera \& Ngirande, 2014). Hassan (2016) concluded in their research paper that HRM practices such as career planning, training, compensation, performance appraisal and employee involvement found to be associated positively with performance.

Recently Lai, Saridakis, Johnstone (2017) observed positive association between HR practices and financial performance which has been differed among SMEs with the higher level of job satisfaction and low job satisfaction. Also studies have revealed that the association declined in SMEs with due to high job satisfaction. The researcher indicated that HRM practices have complementary and synergistic effects on the attitude of the 
workforce those surpass their individuality effects (El-Ghalayini, 2017). Further, he emphasized that there are positive effects of some HRM practices on attitudinal consequences. A study by Sandhya and Sulphey (2014) examined the influence of the previous work experience on HR practices and the psychological contracts of employees and found them to be associated. A fair review of the literature could identify only scant literature related to unfair HR practices.

\section{Objective of the study}

As stated earlier there is no dearth of literature about HRM practices and innumerable studies have been conducted across the globe. However, a fair review of literature failed to identify studies about unfair HRM Practices. No suitable tools to assess unfair HRM practices were also found. The present study is intended to bridge this gap in literature. It is aimed at exploring the attributes of unfair HRM practices prevailing in the private telecom sectors in Kingdom of Saudi Arabia. Towards this a suitable tool to assess unfair HRM practices is also sought to be constructed and validated, It is also an objective to identify the relationship between perceived unfair HRM practices and various demographic factors.

\section{Methodology}

\section{Sample of the study:}

The data for the current research were collected from 120 employees selected randomly from two different private telecom sectors namely Zain (47.5\%) and Mobily (52.5\%), in Kingdom of Saudi Arabia (K.S.A.). All respondents were male with varying experience and age. The details pertaining to the demographics of the sample are also presented.

\section{Tools:}

A fair review of literature could not identify a suitable standardized tool to assess the perceived unfair HRM practices. As such it was decided to construct and validate an appropriate tool to assess the level of unfair HRM practices. Many classical studies have provided the various scientific processes that could be used to construct strong tools (Cabrera-Nguyen, 2010; Kumar \& Beyerlein, 1991; Hinkin, 1998; Worthington, and Whittaker, 2006). Kumar \& Beyerlein (1991) in his pioneering study identified the steps to be taken for item selection, reduction; as well as the reliability and validity of the tool. The pioneering study by Schwab (1980) presented the stages of item generation, the development of the scale and its psychometric evaluation. Worthington, and Whittaker (2006) has also elucidated how to develop scale in similar lines. The present study has taken cues from the above studies to construct the tool.

\section{Creation of item pool}

The items for the present study were gathered after review of the literature on the topic. Hinkin's (1998) guidelines about hot to develop a tool was born in mind while doing this. Though in the initial stage many items were developed, based on the related literature, 10 items were identified after purifying the initial pool.

This was done based on the opinion of Hinkin (1995) about the importance of the length of the scale. He opined that both too long and too short scales would deliver "negative effects on results". Earlier studies, for instance Anastasi (1976) and Schriesheim \& Eisenbach (1991) viewed that an effective way of solving problems associated with demands of time is to maintain the scale short. It also has the advantage of minimizing the problem of response biases, and respondent boredom and fatigue. Substantiating this Carmines \& Zeller (1979) 
The International Journal

ENTREPRENEURSHIP AND SUSTAINABILITY ISSUES

ISSN 2345-0282 (online) http://jssidoi.org/jesi/

2018 Volume 5 Number 4 (June)

http://doi.org/10.9770/jesi.2018.5.4(18)

opined that if the number of items is increased, beyond a certain limit it will not have any further impact on the aspect of reliability. Further Hinkin (1995) also states that proper scale length will minimize a host of response biases, and guaranteeing internal consistency. Based on these studies all required safeguards were taken to maintain the length of the scale at a fair length. 10 items where thus pooled after doing away with double barreled type questions. Another important area that requires care and caution is In order to have face validity, the items were presented in clear, well-organized, and in a manner understood by the respondents.

Scaling is an aspect that requires the exercise of care and caution. Hinkin (1995) opines that a scale must have the quality of generating the required variance between respondents so that statistical analysis is possible. Lissitz \& Green (1975) states that the Coefficient alpha of Likert-type scales normally increase up to five points. However, after this it could level off. Based on this a five point scale (strongly agree, agree, neutral, disagree and strongly disagree) was used in this study. In addition to this scale, the biographical blank sheet was also used in the study to gather the information pertaining to age, gender, marital status etc.

Care has also to be exercised while deciding on the sample size. This is all the more important when Factor Analysis has to be done. In this regard Schwab (1980) identified item-to-response ratio of 1:10. As against this Rummel (1970) stated a requirement of 1:4 and Hoelter (1993) 200. Taking a mean view of these studies the present study collected data from 120 samples.

The tool used in the present investigation was in English language, which was translated into Arabic. The reason behind to translate the questionnaire was to make the respondents understand each item systematically with meaningfulness, and to avoid biases. The researcher took the permission from the company to administer the questionnaire to their employees in advance. Clear instructions were provided to the subjects so as to avoid any confusion with the items. Moreover, the researcher also assured the respondents that the responses would be used for academic purposes and would not be revealed to any higher official at any circumstances. The demographics of the respondents are presented in the following sections (Table 1, Table 2, Table 3).

Table 1. Age profile of the respondents

\begin{tabular}{|c|c|c|}
\hline Categories & Frequency & Valid Percent \\
\hline $18-25$ years & 36 & 30.0 \\
\hline 26-30 years & 33 & 27.5 \\
\hline $31-35$ years & 30 & 25.0 \\
\hline 36-40 years & 12 & 10.0 \\
\hline 41-50 years & 6 & 5.0 \\
\hline 51 years and above & 3 & 2.5 \\
\hline Total & 120 & 100.0 \\
\hline
\end{tabular}

Table-1 shows age categories of the employees working in two different sectors. Out of 120 employees $30 \%$ employees fall under the age categories of 18-25 years, $27.5 \%$ respondents were in the 26-30 years categories, $25 \%$ respondents observed in the case of 31-35 years groups, having 6 respondents in the age categories of 36-40 years which constitutes $10 \%$ respondents and 51 years and above contains only 3 respondents with $2.5 \%$.It is observed from the table that most of the employees employing in the company were younger in age and fewer were in older in age groups.

Table 2. Marital status of the respondents 
The International Journal

ENTREPRENEURSHIP AND SUSTAINABILITY ISSUES

ISSN 2345-0282 (online) http://jssidoi.org/jesi/

2018 Volume 5 Number 4 (June)

http://doi.org/10.9770/jesi.2018.5.4(18)

\begin{tabular}{|l|c|c|}
\hline \multicolumn{1}{|c|}{ Categories } & Frequency & Valid Percent \\
\hline Married & 78 & 65.0 \\
\hline Unmarried & 42 & 35.0 \\
\hline Total & 120 & 100.0 \\
\hline
\end{tabular}

It can be seen from the table 2 that $65 \%$ employees were married $(\mathrm{N}=78)$ whereas, unmarried $(\mathrm{N}=42)$ were $35 \%$. The findings revealed that some of the employees were unmarried in the age groups between 18-40 years which constitutes the $92.5 \%$ of the respondents.

Table 3. Work experiences of the respondents

\begin{tabular}{|l|c|c|}
\hline \multicolumn{1}{|c|}{ Categories } & Frequency & Valid Percent \\
\hline $1-5$ years & 57 & 47.5 \\
\hline 6-10 years & 48 & 40.0 \\
\hline $11-15$ years & 9 & 7.5 \\
\hline $16-20$ years & 6 & 5.0 \\
\hline Total & 120 & 100.0 \\
\hline
\end{tabular}

From the aforesaid table 3, it is observed that most important experience categories are between 1 to 5 years which consists of $47.5 \%$ respondents followed by 6-10 years which consists of $40 \%$ respondents. 11-15 years experienced groups are having $7.5 \%$ respondents, whereas, only 5\% respondents shows in the 16-20 years of experience of categories.

\section{Tool refining}

A variety of statistical techniques are found used for tool refining and purification. The most frequently used techniques are inter-item correlation and Factor analysis (Boyle, 1991; Henson and Roberts, 2006 Hinkin, 1995, 1998). This method has been used by a number of earlier studies (Sulphey and Nisa, 2014; Sulphey, 2015). The present study used both these. According to Boyle (1991) items have to be eliminated if the inter-item correlations exceed .7. According to him "this could help in avoiding too much redundancy and artificially inflated estimates of internal consistency". Based on this no items were eliminated from the pool.

Thereafter Factor analysis was done. The principal component axis method and Varimax rotation with Kaiser Normalization was conducted. The rotations converged at three iterations. Qualification criterion, according to Hinkin (1995) for the judgment factor loading is .40. Since all the items had factor loading value of over .40 no items warranted exclusion. The analysis provided two factors. The details are presented in Table 4.

Table 4. Items and factor loadings

\begin{tabular}{|c|c|c|c|}
\hline No & Item & Factor loading & Item to total correlation \\
\hline \multicolumn{3}{|c|}{ Factor 1} & \\
\hline 1 & Job analysis practices & .603 & $.577 * *$ \\
\hline 2 & Recruitment and selection practices & .627 & $.769 * *$ \\
\hline 3 & Training and development & .917 & $.564 * *$ \\
\hline 4 & Performance appraisal & .615 & $.882 * *$ \\
\hline & Eigen value & \multicolumn{2}{|r|}{6.45} \\
\hline & Per cent of variance explained & \multicolumn{2}{|r|}{64.49} \\
\hline & Cronbach Alpha & \multicolumn{2}{|r|}{.804} \\
\hline \multicolumn{4}{|c|}{ Factor 2} \\
\hline 1 & Compensation and benefit & .889 & .895 \\
\hline 2 & Working conditions & .866 & .907 \\
\hline
\end{tabular}




\begin{tabular}{|l|l|r|}
\hline 3 & Security and health & .750 \\
\hline 4 & Communication practices & .829 \\
\hline 5 & Peer relations & .860 \\
\hline 6 & Intention to stay & .900 \\
\hline & Eigen value & .859 \\
\hline & Per cent of variance explained & .883 \\
\hline & Cronbach Alpha & 1.10 \\
\hline
\end{tabular}

\section{Reliability}

Some of the ways in which reliability is assessed are inter-item correlations, Cronbach Alpha and Split-half (Hinkin, 1995). According to Hair et al. (2006) the rule of thumb for inter-item correlation is that it should exceed 0.50. Cronbach Alpha is another method used for internal consistency reliability, for which the suggested $\boldsymbol{\alpha}$ is .70 (Nunnally, 1978). In the present case both the factors had $\boldsymbol{\alpha}$ values over the stipulated minimum of .79 (Table 4). Kumar \& Beyerlein (1991) suggests that a high $\boldsymbol{\alpha}$ value would suggest the consistent responses for all the items by the subjects. The factor wise items-to-total correlations also suggest high internal consistency reliability (Hair et al., 2006), for both factors. These findings suggest a high reliability of the tool. The scientific construction of a tool to assess unfair HR practices has succeeded in providing a further impetus for further research in this area. It is hoped that this tool will stimulated further researches about unfair HR practices.

The study also intended to find out the level of perceived unfair HR practices among private telecom employees of KSA. Towards this the sample was classified into three groups based on the following grouping:

Those having total score above Mean $+1 / 2$ Standard deviation :: High

Those having total score below Mean $-1 / 2$ Standard deviation :: Low

Those samples having scoring between the above two scores were classified as medium group. Thus those having scores over 31.20 were considered as high group and below 22.69 as low group. Those having scores between 31.20 and 22.69 were of the medium group. Based on this the distribution of the sample was as under (Table 5).

Table 5. Classification of the sample

\begin{tabular}{|c|l|c|c|}
\hline No & \multicolumn{1}{|c|}{ Grouping } & Number & Per cent \\
\hline 1 & High group & 36 & 30.0 \\
\hline 2 & Medium group & 33 & 27.5 \\
\hline 3 & Low group & 51 & 42.5 \\
\hline & Total & 120 & 100 \\
\hline
\end{tabular}

From the table it can be seen that 30 per cent of the sample (36) perceived that their organizations had unfair HR practices. It is however, heartening to note that 41 ( 42.5 per cent) of the sample perceived that their organization is not having any unfair HR practice. Those in the medium group numbered 33 (27.5 per cent). Those in the medium group could on a later stage, based on their change in attitude have the propensity to move to either high or lower group.

It was another objective to examine if there is any relationship between perceived unfair HR practices and the various demographics of the sample. The details are presented in Table 6. 
Table 6. Data and t-value based on marital status

\begin{tabular}{|c|c|c|c|c|}
\hline Marital status & Number & Mean & SD & t-value \\
\hline Married & 78 & 27.78 & 9.25 & 1.492 NS \\
\hline Unmarried & 42 & 25.36 & 6.85 & \\
\hline
\end{tabular}

The results of the t-test show that there is no significant difference between married and unmarried employees regarding their perception about unfair HR practices. However, the mean value of married is found to be higher denoting that they perceive that their organizations had unfair HR practices. This may be due to the higher demands of married people with respect to their specific needs due to their marital status.

An attempt was made to find out if there existed any difference between the samples regarding their perception of unfair HR practices in their respective organizations based on age. Towards this ANOVA was done and the results are presented in Table 7.

Table 7. ANOVA Results based on demographics

\begin{tabular}{|c|c|c|c|c|}
\hline \multicolumn{5}{|c|}{ Based on age } \\
\hline & Sum of Squares & Df & Mean square & $\mathbf{F}$ \\
\hline Between groups & 3035.841 & 5 & 607.168 & $12.273^{*}$ \\
\hline Within groups & 5639.696 & 114 & 49.470 & \\
\hline Total & 8675.467 & 119 & & \\
\hline \multicolumn{5}{|c|}{ Based on family size } \\
\hline Between groups & 418.145 & 2 & 209.072 & $2.962 \$$ \\
\hline Within groups & 8257.322 & 117 & 70.575 & \\
\hline Total & 8675.467 & 119 & & \\
\hline \multicolumn{5}{|c|}{ Based on qualification } \\
\hline Between groups & 1403.800 & 4 & 350.950 & $5.550 *$ \\
\hline Within groups & 7271.667 & 115 & 63.232 & \\
\hline Total & 8675.467 & 119 & & \\
\hline \multicolumn{5}{|c|}{ Based on experience } \\
\hline Between groups & 294.182 & 3 & 98.061 & $1.357 \$$ \\
\hline Within groups & 8381.285 & 116 & 72.252 & \\
\hline Total & 8645.467 & 119 & & \\
\hline
\end{tabular}

The Analysis of Variance has provided some very interesting results. It shows that while there are significant differences in the perception about unfair HR practices with respect to Age and Qualification, no significant difference was found with respect to family size and experience. This result is to a certain extend intriguing, especially the findings regarding age and experience of the respondents.

\section{Conclusions}

This particular research conducted on employees working in private telecom sectors in the Saudi Arabia to explore the understanding of fair or unfair HRM practices. Large number of studies have been conducted on the theme HRM practices on the globe but rarely seen by the researchers initiated a study pertaining to unfair HRM practices. Thereby, the aim of the was to explore the attributes of unfair HRM practices existing in the private telecom sector in K.S.A. 30 per cent of the sample (36) perceived that their organizations had unfair HR practices and 41 (42.5 per cent) of the sample perceived that their organization is not having any unfair HR practice. Albeit, 27.5 per cent were in medium group and those medium group could change the attitude in the later stage towards either higher or lower group. This indicates that unfair existed in the sector. Further the result showed no 
The International Journal

ENTREPRENEURSHIP AND SUSTAINABILITY ISSUES

ISSN 2345-0282 (online) http://jssidoi.org/jesi/

2018 Volume 5 Number 4 (June)

http://doi.org/10.9770/jesi.2018.5.4(18)

significant difference between married and unmarried employees but married employees mean scores are high indicating unfair HRM practices is prevailing in the company.

\section{Suggestions and limitation of the study}

It is observed from the findings that private telecom company in the Kingdom have overall fair HRM practices but unfair also existed in a marginal level. As noted by Guest (2011) that success or failure of HRM practices implementation depends on manager skills and ability. Hence, it is the responsibility of the manager to provide clear job description, adequate training, fair recruitment and selection, security and health practices working condition, well-planned performance appraisal system etc. in the organization to motivate them to perform in an extraordinary manner and to eliminate unfair practices. This research paper has certain limitation like other empirical research. This particular study initiated only on male and small sample size so findings cannot be generalized across the population. It would be better to take adequate sample and different population to make the study more informative to the audience. Finally, the study sparked some new value to the knowledge of study to know the consequences of unfair HRM practices in the telecom sector in the Kingdom.

\section{References}

Al Kahtani, N.S. \& Allam, Z. (2016). A holistic approach to determine the relationships of sociobiographical variables with role ambiguity and role conflict, International Business Management 10(15): 2795-280. http://dx.doi.org 10.5267/j.msl.2018.2.001

Al Kahtani, N.S. \& Nawab, A. K. (2013). Human resource development practices in telecom sector in Saudi Arabia. World Applied Sciences Journal 28(11): 1567-1578. http://dx.doi.org 10.5829/idosi.wasj.2013.28.11.2035

Al Kahtani, N.S.; Nawab, A. K. \& Allam, Z. (2016). Organizational role stress: An empirical perspective of university teachers of Kingdom of Saudi Arabia, International Journal of Applied Business and Economic Research 14(9): 336-355. http://serialsjournals.com/serialjournalmanager/pdf/1465192484.pdf

Ali, N. \& Allam, Z. (2016). Antecedents and outcomes of interpersonal trust and general role stress: The case of Prince Sattam bin Abdulaziz University, International Journal of Economic Research 13(1): 395-411. http://www.serialsjournals.com/serialjournalmanager/pdf/1499334735.pdf

Allam, Z. \& Harish, K.T. (2010). Influence of sociodemographic factors on job burnout and satisfaction among Eritrean medical workers, Nigerian Journal of Psychiatry 8(1): 43-47. http://dx.doi.org/10.4314/njpsyc.v8i1.53308

Allam, Z. (2007). A study of relationship of job anxiety and job burnout with job involvement among bank employees, Management and Labor Studies 21(1): 30-38. http://journals.sagepub.com/doi/abs/10.1177/0258042X0703200109

Allam, Z. (2017). A scientific approach to understand role stress amongst business school teachers, Man in India 97(10): 183-196. http://www.serialsjournals.com/serialjournalmanager/pdf/1500031224.pdf

Anastasi, A. (1976). Psychological testing, 4th ed. New York: Macmillan.

Boxall, P.; Ang, S., Bartram, T. (2011). Analysing the black box of HRM uncovering HR goals, mediators and outcomes in a standardized service environment, Journal of Management Studies 48(7): 1504-1532. http://dx.doi.org/10.1111/j.1467-6486.2010.00973.x

Boyle, G. (1991). Does item homogeneity indicate internal consistency or item redundancy in psychometric scales? Personality and Individual Differences 12(29): 1-294. https://epublications.bond.edu.au/cgi/viewcontent.cgi?referer=https://www.google.lt/\&httpsredir=1\&article=1001\&context=gre g_boyle

Cabrera-Nguyen, P. (2010). Author Guidelines for Reporting Scale Development and Validation Results, Journal of the Society for Social Work and Research 1(2): 99-103. http://dx.doi.org/10.5243/jsswr.2010.8 
Carmines, E.G. \& Zeller, R.A. (1979). Reliability and validity assessment. Beverly Hills: Sage.

Danish, R.Q., Usman, A. (2010). Impact of reward and recognition on job satisfaction and practices on productivity: A study on steel finishing line, The American Economic Review 87(3): 291-313.http://dx.doi.org/10.5539/ijbm.v5n2p159

El-Ghalayini, Y. (2017). Human resource management practices and organizational performance in public sector organization, Journal of Business Studies Quarterly 8(3): 65-80. http://jbsq.org/wp-content/uploads/2017/03/March_2017_4.pdf

Guest, D.E. (2011). Human resource management and performance: Still searching for some answers, Human Resource Management Journal 21(1): 3-13. https://doi.org/10.1111/j.1748-8583.2010.00164.x

Hassan, S. (2016). Impact of HRM practices on employee's performance. International Journal of Academic Research in Accounting, Finance and Management Sciences, 6(1), 15-22. https://doi.org/10.6007/IJARAFMS/v6-i1/1951

Henson, R., Roberts, J. (2006). Use of exploratory factor analysis in published research: Common errors and some comment on improved practice, Educational and Psychological Measurement 66: 393-416. http://dx.doi.org/10.1177/0013164405282485

Hinkin, T. R. (1998). A Brief Tutorial on the Development of Measures for Use in Survey Questionnaires, Organizational Research Methods, 1: 104-21

Hinkin, T. R. (1995). A review of scale development in the study of behavior in organizations, Journal of Management 21: 967-988. https://pdfs.semanticscholar.org/3f90/547405daa34524ee1a002ff65bd5816dea17.pdf

Hoelter, J. W. (1993). The effects of role evaluation and commitment on identity salience, Social Psychology Quarterly 46(2): 140-147.

Jurigová, Z.; Tučková, Z. and Kuncová, M. (2016). Economic sustainability as a future phenomenon: moving towards a sustainable hotel industry, Journal of Security and Sustainability Issues 6(1): 103-112. http://dx.doi.org/10.9770/jssi.2016.6.1(7)

Katou, A. A. and Budhwar, P. S. (2010).Causal relationship between HRM and organizational performance: Evidence from the Greek manufacturing sector, European Management Journal 28(1): 25-39. http://dx.doi.org/10.1016/j.emj.2009.06.001

Korauš, A.; Kaščáková, Z.; Parová, V. and Veselovská, S. (2017). Sustainable economic development through human resource management: social intelligence of managers and performance, Journal of Security and Sustainability Issues 6(3): 457-477. http://dx.doi. org/10.9770/jssi.2017.6.3(11)

Kumar, K. and Beyerlein, M. (1991). Construction and Validation of an Instrument for Measuring Ingratiatory Behaviors in Organizational Settings, Journal of Applied Psychology 76(5): 619-627. https://doi.apa.org/journals/ap1/76/5/619.pdf

Lai, Y.; Saridakis, G. (2013). Employee attitudes, HR practices and organizational performance: What's the evidence? In G. Saridakis\& C.L. Cooper (Eds.). How can HR drive growth? (pp.170-214). Cheltenham: Edward Elgar Publishing Ltd.

Lai, Y.; Saridakis, G. \& Johnstone, S. (2017). Human resources practices, employee attitudes and small firm performance, International Small Business Journal 35(4): 470-494. https://doi.org/10.1177/0266242616637415

Lissitz, R.W.; Green, S.B. (1975). Effect of the number of scale points on reliability: A Monte Carlo approach, Journal of Applied Psychology 60: 10-13.

Mura, L.; Ključnikov, Tvaronavičienè, M.: Androniceanu, A. 2017. Development Trends in Human Resource Management in Small and Medium Enterprises in the Visegrad Group, Acta Polytechnica Hungarica 14 (7): 105-122 http://www.uniobuda.hu/journal/Issue 78.htm

Paauwe, J. and Boselie, P. (2009). HRM and performance: What's next?, Human Resource Management Journal 15(4): 68-83. https://doi.org/10.1111/j.1748-8583.2005.tb00296.x

Prause, G. (2015). Sustainable business models and structures for industry 4.0, Journal of Security and Sustainability Issues 5(2): 159-169. https://doi.org/10.9770/jssi.2015.5.2(3)

Rummel, R. J. (1970). Applied factor analysis. Northwestern University Press. 
The International Journal

ENTREPRENEURSHIP AND SUSTAINABILITY ISSUES

ISSN 2345-0282 (online) http://jssidoi.org/jesi/

2018 Volume 5 Number 4 (June)

http://doi.org/10.9770/jesi.2018.5.4(18)

Sandhya, S.; Sulphey, M. M. (2014). Influence of Previous Work Experience on Psychological Contracts, World Applied Sciences Journal 31(14): 57-62. http://dx.doi. org/10.5829/idosi.wasj.2014.31.arsem.590

Schriesheim, C.A.; Eisenbach, R.J. (1991). Item wording effects on exploratory factor-analytic results: An experimental investigation. Pp. 396-398 in Proceedings of the 1990 Southern Management Association annual meetings.

Schwab, D. P. (1980). Construct validity in organization behavior. In B. M. Staw \& L. L. Cummings (Eds.), Research in organizational behavior 2: 3-43 Greenwich, CT: JAI.

Singh, N.R.; Kassa, B. (2016). The impact of human resource mangment practice on organizational performance-A study on DebreBrehen University, International Journal of Recent Advances in Organizational Behavior and Decision Sciences 1(1): 643-662. http://globalbizresearch.org/files/5045_ijraob_nongmaithem-robindro-singh_biniam-kassa-375648.pdf

Sulphey, M. M.; Nisa, S. (2014). Orientation towards Finances: Testing of ORTOFIN Scale in the Indian Context, Journal of Applied Management and Investments 3(4): 257-264.

Sulphey, M. M.; Alkahtani, N.S. (2017a). Organizational ambidexterity as a prelude to corporate sustainability, Journal of Security and Sustainability Issues 7(2): 335-347. https://doi.org/10.9770/jssi.2017.7.2(13)

Sulphey, M. M.; Alkahtani, N. S. (2017b). Economic security and sustainability through social entrepreneurship: the current Saudi scenario, Journal of Security and Sustainability Issues 6(3): 479-490. http://dx.doi.org/10.9770/jssi.2017.6.3(12)

Tan, C.L.; Nasurdin, A.M. (2011). Human resource management practices and organizational innovation: Assessing the mediating role of knowledge management effectiveness, The Electronic Journal of Knowledge Management 9(2): 155-167. file:///C:/Users/Manuela/Downloads/ejkm-volume9-issue2-article289.pdf

Terera, S.R.; Ngirande, H. (2014). The impact of training on employee job satisfaction and retention among administrative staff members: A case of a selected tertiary institutions, Journal of Social Science 39(1): 43-50. https://pdfs.semanticscholar.org/cc7c/07d06cef13e42d52a178d44fed5134da0b42.pdf

Worthington, R.; Whittaker, T. (2006). Scale development research: A content analysis and recommendations for best practices, Counseling Psychologist 34: 806-838. http://dx.doi.org/10.1177/0011000006288127

Dr. Nasser S. AL-KAHTANI is Associate Professor, College of Business Administration, Prince Sattam bin Abdulaziz University, Kingdom of Saudi Arabia. His research interests include Human Resource Management, Organizational Behaviour, Teaching learning process, etc.

ORCID ID: $\underline{\text { https://orcid.org/0000-0003-3623-3861 }}$

Register for an ORCID ID:

https://orcid.org/register

Copyright (C) 2018 by author(s) and VsI Entrepreneurship and Sustainability Center

This work is licensed under the Creative Commons Attribution International License (CC BY).

http://creativecommons.org/licenses/by/4.0/

(c) (i) Open Access 